\title{
Will highly educated women have more children in the future? Looking at reproductive plans and outcomes
}

\section{Maria Rita Testa*}

"Will highly educated women have more children in the future?" In this contribution, I address this question by looking at both fertility and fertility intentions; i.e., the number of children people plan to have over their reproductive lives. Intended births are highly correlated with actual births, and in low-fertility settings, childbearing has become associated with the couple's agency. ${ }^{1}$ On the other hand, education, which is a marker of income and social status, has remained an important driver of fertility choices. ${ }^{2}$ Hence, understanding the reproductive decision-making of women and men with low, medium, and high levels of education is crucial when seeking to determine whether - and if so, to what extent - there is scope for additional policy interventions aimed at raising fertility levels.

\section{Introduction}

In recent decades, increasing numbers of women have earned a tertiary or a higher education degree. According to diffusion theory, individuals with high levels of education tend to be trendsetters who engage in novel forms of behaviour that are subsequently adopted by other societal groups (Goode 1993; Nazio 2008). Indeed, highly educated couples have driven both the decline and the turnaround in fertility levels observed over the past five decades (Esping-Andersen and Billari 2015). In terms of family planning, highly educated women are expected

\footnotetext{
* Maria Rita Testa, Wittgenstein Centre, Vienna Institute of Demography of the Austrian Academy of Sciences, Welthandelsplatz 2, Level 2, 1020 Vienna, Austria

Email: maria.rita.testa@oeaw.ac.at

1 Here, agency is defined in a general sense as the intrinsic human capacity to make choices and act. "Action depends upon the capability of the individual to 'make a difference' to a pre-existing state of affairs or course of events" (Giddens 1984: 14).

2 In countries where the highly educated women have lower second birth rates than the less educated women, total fertility also tends to be low, and vice versa (van Bavel and Różańska-Putek 2010).
} 
to differ from their less educated counterparts. Past empirical evidence suggests that the relationship between fertility intentions and education is not necessarily identical to the relationship between actual fertility and education: i.e., that a highly educated woman is more likely than a less educated woman to end her reproductive life with fewer children than she had intended to have. This result is counterintuitive, given that education competes with childbearing, and that highly educated women and men may be expected to be more accurate than their less educated counterparts when reporting the number of children they expect to have. One potential reason for this apparent contradiction is the tendency to postpone childbearing and the parity-specific distribution of fertility intentions (Sobotka 2009). If we look at the distribution of highly educated women by their intended number of children, we see a clear clustering around the option of having two children (Testa 2012). However, official statistics show that the average highly educated woman of all cohorts and birth years has far fewer than two children (Sobotka et al. 2015). The question of whether highly educated women will have more children in the future can be rephrased as the question of whether the average highly educated woman will be able to meet her goal of having a two-child family, and will thus be able to overcome the disadvantage of starting her childbearing later in life. The issue is twofold: Will the group who started the low fertility trend continue to have fewer children in the future? How will the behaviour of the members of this group change if they become more numerous, and are thus no longer a small "elite"?

\section{Education and reproductive plans}

Previous studies have provided contradictory findings regarding the relationship between education and fertility intentions. Some studies have documented that highly educated women are more likely than their less educated counterparts to say they want to have or are planning to have a large family (e.g., Heiland et al. 2008; Mills et al. 2008); while other studies have found that better educated women have lower completed fertility levels than less educated women. These apparent discrepancies suggest that unplanned births or early childbearing are the reasons for the higher fertility levels among less educated women (e.g., Musick et al. 2009; Hayford 2009; Hayford and Guzzo 2016). A woman in a high-status occupation may plan from the beginning of her reproductive career to have only a small number of children (Friedman et al.1994), or she may decide later to have fewer children than she had initially planned (Iacovou and Tavares 2011). In general, better educated women are more likely than less educated women to say they want to have their first child later in life (Berrington 2004). This tendency to delay childbearing may cause a woman to end her reproductive life with fewer children than she had initially intended to have, either because of declining fecundity with age, or because of competing activities (Morgan and Rackin 2010). Recently, scholars have suggested that the relationship between education and fertility - and, presumably, fertility intentions - is positive in those countries in which institutional 
arrangements support the compatibility of work and family life, as well as gender equity in the family and in the labour market (Hobson and Oláh 2006; Matysiak 2011; Neyer 2013). A multi-level analysis conducted in the 28 countries of the European Union (Testa 2014) demonstrated that women of reproductive ages tend to invest more in both human capital and family size if they live in an institutional context that supports work-life balance; that is, in a country where having a career and having children are not seen as mutually exclusive choices. Interestingly, this study has suggested that both being highly educated and living in a country with a high share of college educated women are positively associated with wanting to have one or two children. A hypothesis that stems from this empirical evidence asserts that supporting the reconciliation of work and family life for highly educated women of advanced reproductive ages might have positive spill-over effects for highly educated women who have yet to complete their reproductive careers (Testa 2014).

\section{Educational differences in intended and actual childbearing}

When making assumptions about future trends in fertility among highly educated women, the first issue to consider is whether these women want to have more children than they currently have. In earlier research, I demonstrated that highly educated women are no less likely than their less educated counterparts to say they want to have two children (Testa 2012). The intention to have a two-child family is the predominant norm among women and men of all educational levels. One explanation for the near-universality of this normative level is that there are specific reasons for wanting to have one or two children that are shared by people of all social strata: i.e., the desire to become a parent and the desire to ensure that the first child has a companion. An alternative explanation for the prevalence of the twochild norm is that after controlling for age, highly educated women and men are more likely than their less educated counterparts to be observed at relatively early stages of their reproductive careers, since they tend to delay childbearing, and are thus unlikely to have started realising their fertility plans. Thus, the lifetime fertility intentions of highly educated people are artificially inflated, especially if they are being monitored at low parity levels (zero or one child). Meanwhile, less educated women at parity zero are more selected; i.e., they may be less family oriented or they may have yet to encounter the obstacles and experiences that lead many women with children to reduce their initial intentions. If this discrepancy is not merely the result of a selection bias, the relatively high fertility intentions expressed by highly educated women may be seen as a sign that their fertility levels could increase in the future. If we assume that the fertility levels of the highly educated will converge with the fertility levels of their least educated counterparts, we may expect that in the years to come, fertility levels will increase, especially in countries in which the fertility gap between educational groups is large, like the Eastern European countries (among the female cohorts born in the 1960s, the difference in 
the number of children born to women with high and with low levels of education is almost one child in Poland, Slovakia, Romania, and Russia); and will be lower in countries in which the differences in fertility levels by education are smaller, like the Scandinavian countries (the differences in completed fertility range from 0.04 in Finland to 0.17 in Norway). Interestingly, for the cohort born in 1972, the countries with the largest differences in completed fertility by education are those with the lowest completed fertility levels; while the countries with the smallest differences in completed fertility by education are those with the highest completed fertility levels (Sobotka et al. 2015).

\section{Forces supporting a positive education-fertility link}

Prior to the fertility transition, there was a clear positive relationship between social status and the number of surviving children. With the decrease in infant mortality - a trend that began in the higher social classes in almost every country - and the subsequent decline in fertility, a negative or neutral status-fertility relationship emerged (Skirbekk 2008). In recent years, there has been a negative relationship between educational attainment and first births, mainly due to the postponement of childbearing (see, among others, Brand and Davis 2011; Santarelli 2011; MartínGarcía and Baizán 2006; Billari and Philipov 2004; Rindfuss et al. 1996). This trend is attributable in part to the conflict between enrolment in education and childbearing (Blossfeld and Huinink 1991). Higher income couples tend to want their children to reach at least the same levels of social and economic status as they have; which may mean having fewer children, and at a later stage of life (Dalla Zuanna 2007). Another potential causal mechanism could run in the opposite direction: women who have children while still enrolled in education are less likely to achieve a high level of education (Cohen et al. 2011).

By contrast, a positive relationship between education and fertility after the transition to parenthood has been documented in several countries (Hoem and Hoem 1989; Hoem et al. 2001; Köppen 2006; Gerster et al. 2007; Kravdal and Rindfuss 2008). The sign of this association has been attributed to the effect of "uncontrolled" unobserved heterogeneity, which is interpreted as family proneness (Kravdal 2001; Kravdal 2007; Kreyenfeld 2002). According to this interpretation, once a woman has decided to become a mother, education has a positive effect on her propensity to have an additional child. Thus, a woman with strong family proneness may be expected to interrupt her working career to devote herself to childbearing and childrearing. Importantly, failing to account for such a self-selection mechanism in parity-specific modelling would result in biased estimates that suggest that there is a positive relationship between a woman's education and the progression to a second (or higher) birth order. Scholars have also offered substantive arguments for why a highly educated woman might have a greater propensity to have an additional child than a less educated woman. For example, a highly educated woman may have a relatively secure position in the labour market, as better educated women 
are especially likely to have a protective labour contract, a flexible work schedule, or a stable position in the public sector (Esping-Andersen 2013). In addition, a highly educated woman may have a relatively high family income that allows her to outsource child care (Ermish 1989). Moreover, a highly educated woman may be especially likely to appreciate the emotional returns of parenthood, given the diffusion of more child-friendly preferences among "cultural elites" (Kravdal 2001). Other scholars have argued that some highly educated women may not be as career-oriented as is commonly assumed (Sobotka and Testa 2006); and that these women are especially likely to be in a gender-equal relationship, which is known to stimulate the formation of a second birth intention (Mills et al. 2008) and the progression to higher birth orders (Brodmann, Esping-Andersen and Güell 2007; Duvander, Lappegård and Andersson 2010).

All of these arguments suggest that the increase in the number of highly educated women does not necessarily imply that a decrease in third birth order fertility is inevitable. In Italy, for example, education has been found to have a positive effect on the propensity to have an additional (a second or a third) child among women born in the northern regions of the country in the 1970s and the 1980s. This finding supports the claim that both the decline and the turnaround in fertility levels are driven by the same social group: i.e., highly educated couples (Impicciatore and Dalla Zuanna 2016). An analogous situation might be observed in other European and low-fertility settings (Esping-Andersen 2009; Esping-Andersen and Billari 2015).

\section{Concluding remarks}

I conclude with some reflections on the expectations for fertility among highly educated women in light of the literature, the empirical evidence, and the hypothesised mechanisms outlined above. First, a further postponement of motherhood among highly educated women may be predicted, as we can assume that highly educated women will continue to condition their start of childbearing on the achievement of other life goals, like finding stable employment or getting married. This is particularly likely to be the case in countries that have been severely affected by economic crises, and thus have high unemployment rates (Goldstein et al. 2013), increasingly precarious employment arrangements, and financial challenges (Testa and Basten 2014). Cohabitation, especially in the form of a prelude to marriage, can smooth the negative education-fertility link, even though fertility is still more likely to occur within marriage (Hiekel et al. 2014). It is difficult to make any predictions for the future use of contraception. Research conducted in the US has shown that unintended or miss-timed fertility is still more prevalent among women with low than with high levels of education (Hayford and Guzzo 2011). A similar observation has been made for Italy, where it was found that the transition to a third child is often unplanned among women with low levels of education (Castiglioni et al. 2001). Second, it may be expected that highly educated women 
will become more likely to have two or more children if the incomplete gender revolution - i.e., the revolutionary change in women's roles proposed by EspingAndersen (2009) - evolves into a completely gender-equal system in which partners with similar levels of education will both pursue careers and evenly share in home production. Facilitating the reconciliation of work and family life and promoting gender equality in the family and in the labour market might help to resolve the role conflict that seems to be at the heart of the persistently low fertility levels in ageing societies. However, in predicting future fertility trends, it is important to consider the migration backgrounds of highly educated women. Having a high educational level increases an individual's ability to meet settled fertility targets, but having certain capacities and the skills necessary to master one's life in a given geographical context does not necessarily translate into having these skills in other socioeconomic, cultural, and geographical contexts (Wingens et al. 2011).

\section{References}

Berrington, A. 2004. Perpetual postponers? Women's, men's and couple's fertility intentions and subsequent fertility behaviour. Population Trends 10: 9-19.

Billari, F. C. and D. Philipov 2004. Education and transition to motherhood: a comparative analysis of Western Europe. European Demographic Research Papers, No. 3. Vienna Institute of Demography/Austrian Academy of Science.

Blossfeld, H.-P. and J. Huinink 1991. Human capital investments or norms of role transition? How women's schooling and career affect the process of family formation. American Journal of Sociology 97: 143-168.

Brand, J. and Davis, D. 2011. The impact of college education on fertility: Evidence for heterogeneous effects. Demography 48(3): 863-887.

Brodmann, S., G. Esping-Andersen, and M. Güell 2007. When fertility is bargained: second births in Denmark and Spain. European Sociological Review 23(5): 599-613.

Castiglioni, M., Dalla Zuanna, G. and M. Loghi 2001. Planned and unplanned births and conceptions in Italy, 1970-1995. European Journal of Population 17(3): 207-233.

Cohen, J. E., Ø. Kravdal, and N. Keilman 2011. Childbearing impeded education more than education impeded childbearing among Norwegian women. Proceedings of the National Academy of the United States of America 108(29): 11830-11835.

Dalla Zuanna, G. 2007. Social mobility and fertility. Demographic Research 17(15): 441-464.

Duvander, A. Z., T. Lappegård and G. Andersson 2010. Family policy and fertility: fathers' and mothers' use of parental leave and continued childbearing in Norway and Sweden. Journal of European Social Policy 20(1): 45-57.

Esping-Andersen, G. 2009. The incomplete revolution. Adapting to women's new roles. Cambridge: Polity Press.

Esping-Andersen, G. (ed.) 2013. The fertility gap in Europe: singularities of the Spanish case. Welfare projects. "La Caixa” Foundation, Social Studies Collection No. 36.

Esping-Andersen, G. and F. C. Billari 2015. Re-theorizing family demographics. Population and Development Review 41(1): 1-31. 
Friedman, D., M. Hechter, S. Kanazawa 1994. A theory of the value of children. Demography 31(3): 375/401.

Gerster, M., N. Keiding, L. B. Knudsen, and K. Strandberg-Larsen 2007. Education and second birth rates in Denmark 1981-1994. Demographic Research 17(8): 181-210.

Giddens, A. 1984. The constitution of society. Outline of the theory of structuration. Berkeley, CA: University of California Press.

Goldstein, J., M. Kreyenfeld, A. Jasilioniene, K. Örsal, D. Dilan 2013. Fertility reactions to the "Great Recession" in Europe: Recent evidence from order-specific data. Demographic Research 29: 86-104.

Goode, W. J. 1993. World changes in divorce pattern. New Haven, CT: Yale University Press.

Hayford, S. R. 2009. The evolution of fertility expectations over the life course. Demography 46(4): 765-783.

Hayford, S. R. and K. B. Guzzo 2016. Fifty years of unintended births: education gradients in unintended fertility in the US 1960-2013. Population and Development Review 42(2): 313-341.

Heiland, F., Prskawetz, A., and Sanderson, W. C. 2008. Are individuals' desired family sizes stable? Evidence from West German panel data. European Journal of Population 24(2): 129-156.

Hiekel, N. and T. Castro-Martín 2014. Grasping the diversity of cohabitation: fertility intentions among cohabiters across Europe. Journal of Marriage and Family 76(3): 489-505.

Hobson, B. and L. Oláh 2006. Birthstrikes? Agency and capabilities in the reconciliation of employment and family. Marriage and Family Review 39(3-4): 197-227.

Hoem, B. and Hoem, J. M. 1989. The impact of women's employment on second and third births in modern Sweden. Population Studies 43: 47-67.

Hoem, J. M., Prskawetz, A. and Neyer, G. 2001. Autonomy or conservative adjustment? The effect of public policies and educational attainment on third births in Austria 1975-96. Population Studies 55: 249-261.

Iacovou, M. and L. P. Tavares 2011. Yearning, learning, and conceding: (some of ) the reasons people change their childbearing intentions. Population and Development Review 37(1): 89-123.

Impicciatore, R. and G. Dalla Zuanna 2016. The impact of education on fertility. Changes across cohorts and south-north differences. Quality and Quantity 51(5): 2293-2317.

Köppen, K. 2006. Second births in western Germany and France. Demographic Research 14(14): 295-330.

Kravdal, Ø. 2001. The high fertility of college educated women in Norway: an artifact of the separate modelling. Demographic Research 5(6): 187-216.

Kravdal Ø. 2007. Effects of current education on second- and third-birth rates among Norwegian women and men born in 1964: Substantive interpretations and methodological issues. Demographic Research 17: 211-246.

Kravdal, $\varnothing$. and R. R. Rindfuss 2008. Changing relationships between education and fertility: A study of women and men born 1940 to 1964. American Sociological Review 73: 854-873. 
Kreyenfeld, M. 2002. Time-squeeze, partner effect or selfselection?: an investigation into the positive effect of women's education on second birth risks in West Germany. Demographic Research 7: 15-48.

Martín-García, T. and P. Baizán 2006. The impact of the type of education and of educational enrolment on first births. European Sociological Review 22(3): 259-275.

Matysiak, A. 2011. On the interdependencies between fertility and women's labour supply. European Studies of Population. Springer.

Mills, M., Mencarini, L., Tanturri, M. L., and Begall, K. 2008. Gender equity and fertility intentions in Italy and the Netherlands. Demographic Research 18(1): 1-26.

Morgan S. P. and H. Rackin. 2010. The correspondence between fertility intentions and behaviour in the United States. Population and Development Review 36(1): 91-118.

Musick, K., England, P., Edgington, S., and Kangas, N. 2009. Education differences in intended and unintended fertility. Social Forces 88(2): 543-572.

Nazio, T. 2008. Cohabitation, family and society. New York: Routledge.

Neyer, G. 2013. Welfare states, family policies, and fertility in Europe. In The demography of Europe, 29-53. Springer Netherlands.

Rindfuss, R. R., S. P. Morgan, and K. Outt 1996. Education and the changing pattern of American fertility: 1963-1989. Demography 33(3): 277-290.

Skirbekk, V. 2008. Fertility trends by social status. Demographic Research 18(5): 145-180.

Sobotka, T. 2009. Sub-replacement fertility intentions in Austria. European Journal of Population 25(4): 387-412.

Sobotka, T. and M. R. Testa 2006. Attitudes and Childlessness in Europe. In People, population change and policies: Lessons from the Population policy acceptance study, eds C. Höhn, D. Avramov and I. Kotowska. Springer Netherlands.

Sobotka, T., K. Zeman, M. Potančoková, J. Eder, Z. Brzozowska, E. Beaujouan, A. Matysiak 2015. European fertility datasheet 2015. Vienna Institute of Demography/Wittgenstein Centre for Demography and Global Human Capital (IIASA, VID/ÖAW, WU).

Testa, M. R. 2012. Family sizes in Europe: evidence from the 2011 Eurobarometer survey. European Demographic Research Paper, No. 2. Vienna Institute of Demography, Austrian Academy of Science.

Testa, M. R. 2014. On the positive correlation between education and fertility intentions in Europe: individual- and country-level evidence. Advances in Life Course Research 21: 28-42. Open access.

Testa, M. R. and S. Basten 2014. Certainty of meeting fertility intentions declines in Europe during the 'Great Recession'. Demographic Research 31(23): 687-734.

Van Bavel, J. 2012. The reversal of gender equality in education, union formation and fertility in Europe. Vienna Yearbook of Population Research 10: 127-154.

Van Bavel, J. and J. Różańska-Putek 2010. Second birth rates across Europe: interactions between women's level of education and child care enrolment. Vienna Yearbook of Population Research 8: 107-138.

Wingens, M., H. deValk, M. Windzio, and C. Aybek 2011. The sociological life course approach and research on migration and integration. In A life course perspective on migration and integration, eds Wingens, M., M. Windzio, H. de Valk and C. Aybek, 1-27. Springer. 